\title{
Using of Selected Social Media in Slovakia and Poland - Comparative Study
}

\author{
Sebastian Kot \\ Czestochowa University of Technology, Faculty of Management \\ Email: sebacat@zim.pcz.czest.pl \\ Martina Ferencová \\ Pavol Jozef Šafárik University in Košice, Faculty of Public Administration \\ Corresponding Author: mferencov@gmail.com \\ Lukáš Kakalejčík \\ Technical university of Košice, Faculty of Economics \\ Email: lukas.kakalejcik@tuke.sk
}

\section{Doi:10.5901/mjss.2016.v7n3s1p113}

\begin{abstract}
Web 2.0 significantly affects the way how companies carry out product promotion. The Internet is almost infinite source of information, including brand and product information. As users browse the Internet in order to find solution that will fulfill their needs, content generated by company can affect consumer's decision in purchasing process. This article was focused on determining whether online media are used while searching information about products before purchase and whether users from Slovakia and Poland complete the purchase based on the information gathered from these media. The results of questionnaire survey shown that there is not significant difference between the use of selected online media for intended purchase between Slovak and Polish customers. However, difference between customers from selected countries was found in online media usage in already completed purchases. It was also found that emerging media in the environment of the Polish market are used in a greater way than in the Slovak market.
\end{abstract}

Keywords: social media, product, online marketing, marketing strategy.

\section{Introduction}

Currently, consumers can choose from various range of goods and services. Due to strong competition on the market, organizations and enterprises are foced to ongoing market analysis, analysis of supply and demand, and needs and requiriments of the consumers. Marketing and application of marketing tools (such as social media, search engines etc.) has the irreplaceable place in each competitive company that want react to change in patterns in consumer behavior. This is the base for the marketing to be constantly innovated in order to provide answers to the questions consumers ask during purchasing process (Bajdor, Brzeziński, 2013). Social media, or in general, online media, are not emerging trend of promotion anymore. It is a common way of product promotion as consumers have become more familiar with available technology and media that use this technology. Online media give companies the opportunity to promote their products in engaging, interactive way. This possibility is especially crucial in times when the promotion of the product should be as same attractive as the product itself (Ferencová, Hudáková, 2013; Chovancová, Rusko, 2008).To extend the message of the company to the multiple groups of potential customers, the Internet is the most suitable and easily available channel (Vejačka, 2015).On the other hand, consumer's ability to search, browse and consume the product related content has improved dramatically. Due to this fact, companies have to market their products to smart customer who is able to switch product distributor in couple of clicks once the expectations of the customer are not met (Trenz, 2015). This is why the product benefits should be communicated preciously. As customer's satisfaction is based on the ability to satisfy its needs, he purchases more and become stable customer, prioritize company's products against competition's and can also provide ideas about product refinement (Dima, Man, Kot, 2010). In this paper, we present how online media are used in pre-purchase stage of buying cycle, during which customers gain information and boost their knowledge about purchased product. 


\section{Theoretical Frameworks}

Consumer is a focal element of each marketing system (Kretter et al., 2008). In the environment of online media, his importance is even more significant. Consumer affects sales of products and associated financial income of manufacturers and service providers. To ensure their prosperity, companies should monitor the market and listen to the voice of consumer (Kincl et al., 2004) because adjusted message can positively change customer behavior and generate more revenue. Consumer behavior is behavior shown by consumers during search, purchase, use and evaluation of goods and services which are expected to satisfy the needs of consumers (Schiffman et al., 2014) taking their preferences and habits into account. It is also investment into the time dedicated to searching and processing the information about products (Kuss, Tomczak, 2004). Thus, the main focus of consumer behavior research is on prepurchase behavior.

Once the company understands consumer behaviour, it should choose communication channels that will help achieve its marketing goals. And online media might be the part (or can be considered as a part) of company's communication strategy. Online social media can be defined as open, interactive online applications that encourage an informal user networks. Users create and share different content within these networks, such as personal experiences, opinions, attitudes, videos, music or photos (Karlíček, Král, 2011), and anyone can access the content by contributing or response. In summary, we can say that social media represent tools allow users to create content (user generated content) and distribute it by the Internet (Sterne, 2011).A communication based on a trusted relationship can be developed into marital relationship, because the components of the latter are trust, respect and admiration (Vlăduțescu, 2012).

While Sterne considers social media to be social networks, blogs, mircroblogs, websites, discussion forums, search engines and so on (Sterne, 2011), Kawasaki and Fitzpatrick (2014) understand social media narrower, equate them with social networks. Anyway, detailed division of online social media is considered to be very difficult, because the individual media overlap (Karlíček, Král, 2011). Social media helppopularize the actual topic and researchin the field ofpublic administration of EU countries, higher education andgenderdiversity (Kot, Ślusarczyk, 2012; Ślusarczyk, Broniszewska, 2014; Constantin, 2013; Ślusarczyk, Herbuś, 2015; Tej, Ali Taha, Sirková, 2013; Butoracová Šindleryová, 2015; Goncharuk, 2015). It can be said, that communication via social media is one of the fields that have turned into a communication universe defined by Smarandache and Vlăduțescu (2014) which has its own identity and profile.

Social networks (such as Facebook, Twitter, Linkedln and many more) could be considered to be one of the most important media used to quick outreach of company's content and have the highest potential to make content go viral (Halligan, Shah, 2014).Social media allow companies to build relationships with other users within the network. This relationship is represented by being "fan" (Facebook) or "follower" (Twitter). Social networks are based on social relationships and they develop conscious of existence and membershipVlăduţescu (2008). Social networks could be devided to mostly personal (Facebook, Twitter, Google+, MySpace) or mostly professional (Linkedln) (Janouch, 2010), however, companies usually operate on each of these networks. Blog is another effective marketing tool for a business (Parker, 2010).A blog is a personal journal in which posts are added in chronological order. This feature of blogs changed with the advent of social media arrival to the business. As blogs are usually available at no cost, there are suitable for small- and medium-sized enterprises that are most sensitive to market factors (Pietrasieński, Ślusarczyk, 2015). A welldesigned web presentation (including websites of retailers and manufacturers) are also used for communication with target customers. To address them, various alternative online media can be used, such as sharing photos by Flickr, YouTube video search engine, Pokec (one of the most popular social networks in Slovakia), Foursquare (social locationbased service smartphone app) (Gallo, 2012) or Trip Advisor (tourist-oriented website which works on the basis of free sharing travel guides, information about hotels, destinations and tourist attractions, provides reviews and information useful in planning the trip) (Baglieri, Consoli, 2008).

\section{Research in Area of Social Media}

Study of Advertising Research Foundation (2012) was conducted with use of comprehensive analysis of several research partners and sponsors. Analysis was conducted in three phases. Results of this study shown, that in order to acquire certain product, majority of users use information from brand/company website $(47 \%)$, search engines (43 \%) and reviews (consumer-generated: $41 \%$, expert: $40 \%$ ). Detailed distribution of selected online media use is presented on Figure 1. 


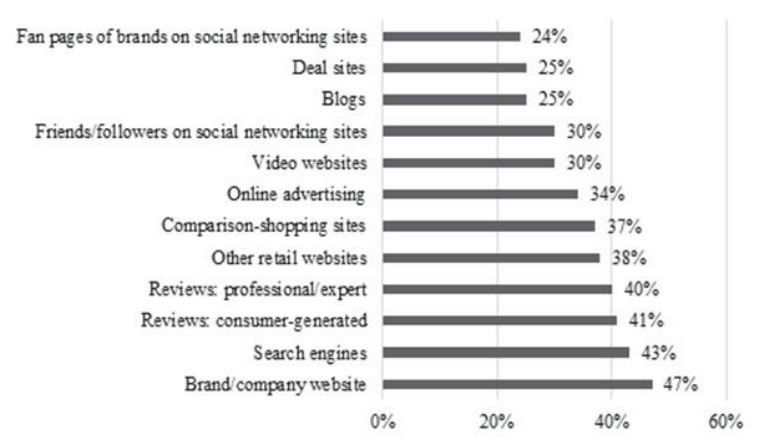

Figure 1. Use of selected online media to acquire product

Source: Advertising Research Foundation (2012)

Survey conducted by Mohammadpour et al. (2014) proved that value created by social media marketing affects the attitude towards shopping via Internet. In addition, social media marketing has a positive impact on relational, brand and value capital of promoted company. Another of the research conducted by Ezumah (2013) showed that only $5 \%$ of participant use social networks to make decision connected to purchase of the product. Wu and Lee (2012) studied the variables of blog trustworthiness, product attitude, blog involvement and derived variables. Results of their research have shown that consumer's involvement in blog influences purchase intention. However, trustworthiness of blog does not affect consumer purchase intention.

\section{Objective and Methods}

The aim of this paper was to identify which of the selected online media (social media, search engines, price comparison websites and deal sites) are used during research phase of the purchasing process for gathering information about products users want to purchase. The intent to purchase a product, as well as realized purchase of a product, was the main focus of this study. The methodology and methods covered in our previous work (Ferencová, Jeleňová, Kakalejčík, 2015) were used. Nevertheless the Internet activity is measure able, it was not possible to collect data for each source (websites, social media, etc.). Moreover, by studying particular websites, we would not have the overall information about general consumer behaviour but it would be focused solely on one or several sources. Based on this fact, the results would not have broader informative value. Instead of that, we used questionnaire survey so we could capture the behaviour across all examined sources by users. Moreover, it was not fixed to particular source so we captured generalized behaviour of users. The increment of observed sample extended our research to the international level. Previous study was focused solely on the Slovak market. By gaining data from similar target group from Polish market, we were able to conduct a comparative study. The subject of our interest consisted from the target group in the age category of 20-29 years. Because study programme of management prepare students for working in all sectors of the economy (including manufacturing, trade and services); students of these programmes were addressed. The selection of the sample was influenced by the fact that these students are not only real and potential customers who are actively using observed online media but also current and potential employees, managers and business owners or service providers therefore people who could use the results of the survey in practice for more effective communication with the target audience.

Based on objective of survey three hypotheses were formulated:

H1: We assume that would not Slovak and Polish users use the selected online media the same way to find information about the product before the purchase.

$\mathrm{H} 2$ : We assume that the Slovak and Polish users did not purchase equally based on information obtained through selected online media.

\section{Sample, Material, Procedure and Data Analysis}

The observed sample consisted of 158 students of one university faculty from Slovakia and one from Poland, selected by 
convenience sampling. The sample included only students of management - University of Prešov in Prešov (75) and Czestochowa University of Technology (83). Average age of participants was 22.80 years (SD $=1.40$ ), with minimum 19 and maximum 26 years. Most of the sample were women (79.11\%), reflecting a higher proportion of women students in these faculties. At the bachelor level of study studied $23.42 \%$ of respondents, at the master level of study studied $76.58 \%$ of the respondents. Full-time or part-time job have $58.86 \%$ of respondents.

The Questionnaire of social media usage consists of 17 items. In this paper are presented the findings based on the answers of two of these items. Respondents answer each of these items using a five-point scale, from $1=$ definitely yes to $5=$ definitely not. Their task was to indicate for each of the selected 16 social media if they use those social media to search for product information and whether they purchase a product based on the information from the specific medium. In the same way they assess use of search engines, price-comparison sites and deal sites.

A paper-version of the questionnaire was distributed in February 2015 and online version of the questionnaire was distributed in March and April 2015. The data were analysed using the software Stat Soft Statistica. Because the data are not normally distributed, for the analysis of data were used nonparametric statistical methods. Mann-Whitney test was used for the detection of differences. Data were analysed using descriptive statistics too (mode, mean, frequency tables).

\section{Results and Discussion}

The main objective was to determine which of the social media are among most used ones by respondents while searching information about the product that they want to buy and whether they use social networking sites, search engines, deal sites and price-comparison websites.

The survey results showed that the respondents would search for information about the product they intend to buy mostly with use of search engines such as Google or Bing (91.14\%), seller's website (69.62\%), price-comparison websites (63.29\%) deal sites (62.66\%) and forums (62.66\%). Higher position of use of deal sites and price-comparison websites indicates that the price is important for while buying and it is clear that users are interested to buy the cheapest product possible. On the other hand, social networks would not be the primary source of information about products because among selected social networks Facebook, Twitter, YouTube, Google+, Instagram, Linkedln, MySpace, and Pokec users would more widely use only social network Facebook (44.94\%) and YouTube (43.67\%). Based on this results, we drawn two following conclusions: 1) other social networks are not sufficiently used for purchasing in the market environment of Slovakia and Poland; 2) users use social networks for the primary purpose of their creation - to communicate with other users - not to find information about products.

By comparison of these results with those that discuss already made purchase of product based on information obtained from selected online media, it is clear that those numbers reached lower values than in the case of intended purchase. The mostly used sources of information in case of purchase made were search engines (73.42\%), seller's website $(66.46 \%)$, price-comparison websites $(58.23 \%)$ and discussion forums $(36.08 \%)$. The fact that users used presented online media less often when actually purchased the product might be a consequence of disalignment between user's informational needs with available information as well as consequence of non-optimalized user experience. This results suggest that companies and organizations offering goods and services should pay more attention to recognition of needs of their potentional clients. It's important to bear in mind that information that users find, could also discourage them from potentional purchase. Besides, companies should also focus on building customers' trust in the online environment. When compared intended purchase with real purchase, results reached the same level only in deal sites use (62.66 \%).It again demonstrates the importance of the price as a part of marketing mix.

If we analyze the modal responses in the already conducted purchases based on information obtained from selected online media, the highest frequency of answers "definitely yes" was found in search engines (39.24\%), seller's website (31.10\%), price-comparison websites (25.94 \%), deal sites (25.32\%) and the social network Facebook (15.19\%). For other online media was monitored modal response in the incidence of less than $15 \%$. Compared with the overall results it is clear that only about half of the users have used this source of information for buying desired product. The result may be a consequence of several factors. First, online marketing strategy of companies is composed of several media cohesion, while the user is not sure if the currently selected media was crucial during the purchasing process. The second reason may be the failure to recognize the influence of medium for purchasing behaviour.

When comparing the occurrence of modal response "definitely yes" in a separate category of social networks (except the social network Facebook, which was analyzed above) it can be observed that the greatest incidence of this response is a social network YouTube (6.96\%). Other social networks had not even reached the $5 \%$ limit. Based on this detection, it can be argued that social networks don't play an important role in the purchasing process for consumers. This does not mean that companies should not use them for building the brand awareness and engagement of the target 
groups. However, we recommend to track return on investment in selected social networks, and in this case, we consider brand awareness to be a suitable performance metric for efficiency determination.

While testing the $\mathrm{H} 1$ hypothesis, it was not possible to reject the null hypothesis because the difference in the use of selected online media to gather information for the intended purchase between Slovak and Polish users was statistically significant only in some media. Based on the results it can be concluded that if respondents were in the situation in which they should buy the product, they would search for information differently only in use of search engines, seller's website, selected social networks and Foursquare application. Detailed results are presented in Table 1.

Table 1. Country differences in the use of selected online media for searching information about product of intended purchase

\begin{tabular}{|c|c|c|c|c|c|c|}
\hline \multirow{2}{*}{ Variable } & \multicolumn{2}{|c|}{ Slovakia } & \multicolumn{2}{|c|}{ Poland } & \multirow{2}{*}{ U } & \multirow{2}{*}{ Z } \\
\hline & M & SD & M & SD & & \\
\hline \multicolumn{7}{|l|}{ Social Media } \\
\hline Seller's website & 1.84 & 1.13 & 2.42 & 1.15 & 2124.0 & $-3.44^{*}$ \\
\hline Discussion forums & 2.53 & 1.12 & 2.39 & 1.31 & 2774.0 & 1.18 \\
\hline Website of manufacturer (despite fact that it is not the seller) & 2.73 & 1.34 & 2.63 & 1.15 & 2982.5 & 0,45 \\
\hline Facebook & 2.75 & 1.42 & 2.75 & 1.24 & 3079.5 & -0.11 \\
\hline YouTube & 3.21 & 1.44 & 2.87 & 1.18 & 2715.5 & 1.38 \\
\hline Blogs & 3.21 & 1.29 & 2.92 & 1.30 & 2691.5 & 1.46 \\
\hline Google+ & 4.05 & 1.38 & 3.37 & 1.24 & 2118.0 & $3.46^{*}$ \\
\hline Instagram & 4.19 & 1.20 & 3.84 & 1.24 & 2580.0 & 1.85 \\
\hline TripAdvisor & 4.27 & 1.24 & 3.98 & 1.16 & 2536.5 & 2.00 \\
\hline Emails of the company & 3.37 & 1.29 & 3.13 & 0.99 & 2715.0 & 1.38 \\
\hline Twitter & 4.39 & 1.12 & 3.94 & 1.14 & 2329.5 & $2.72^{*}$ \\
\hline Linkedln & 4.47 & 1.03 & 3.89 & 1.09 & 2065.5 & $3.64^{*}$ \\
\hline Pokec & 4.56 & 1.00 & 4.00 & 1.13 & 2118.0 & $3.46^{*}$ \\
\hline MySpace & 4.56 & 0.91 & 3.98 & 1.05 & 2080.0 & $3,60^{*}$ \\
\hline Foursquare & 4.64 & 0.87 & 4.04 & 1.15 & 2092.0 & $3.55^{*}$ \\
\hline \multicolumn{7}{|l|}{ Search engines, price comparison websites and deal sites } \\
\hline Search engines (e.g. Google) & 1.24 & 0.61 & 1.63 & 0.98 & 2443.5 & $-2.33^{*}$ \\
\hline Price comparison websites (e.g Heureka.sk) & 2.16 & 1.23 & 2.39 & 1.04 & 2604.5 & -1.76 \\
\hline Deal sites (e.g. Zl'avadňa) & 2.48 & 1.23 & 2.33 & 1.08 & 2957.5 & 0.53 \\
\hline
\end{tabular}

Although the hypothesis $\mathrm{H} 1$ has not been confirmed we consider the detection of difference in the use of selected social networks (Google+, Twitter, Linkedln, Pokec, MySpace) and applications Foursquare to be important. Based on comparison of Slovak and Polish users in connection with the purchase of the product based on information received from selected online media, it can be concluded that there were found differences in the use of majority of observed media. Hypothesis $\mathrm{H} 2$ was therefore confirmed. The differences in shopping behavior of Slovaks and Poles were not detected only in use of search engines, social networking site Facebook, blogs and e-mails sent by companies. Detailed results are displayed in Table 2.

Table 2. Country differences in the use of selected online media for searching information about purchased product

\begin{tabular}{|c|c|c|c|c|c|c|}
\hline \multirow{2}{*}{ Variable } & \multicolumn{2}{|c|}{ Slovakia } & \multicolumn{2}{|c|}{ Poland } & \multirow{2}{*}{$U$} & \multirow{2}{*}{ z } \\
\hline & M & SD & $\bar{M}$ & SD & & \\
\hline \multicolumn{7}{|l|}{ Social Media } \\
\hline Seller's website & 2.21 & 1.31 & 2.31 & 1.01 & 2542.5 & $-1.98^{*}$ \\
\hline Website of manufacturer (despite fact that it is not the seller) & 2.89 & 1.29 & 2.69 & 1.06 & 2487,0 & $2,18^{*}$ \\
\hline Facebook & 3.01 & 1.55 & 2.88 & 1.26 & 2834.5 & 0,97 \\
\hline Discussion forums & 3.04 & 1.22 & 2.72 & 1.22 & 2152.5 & $3.34^{*}$ \\
\hline Emails of the company & 3.13 & 1.30 & 3.11 & 1.19 & 3030.5 & 0.28 \\
\hline Blogs & 3.26 & 1.38 & 3.07 & 1.31 & 2591.5 & 1.12 \\
\hline YouTube & 3.66 & 1.27 & 3.18 & 1.24 & 1749.5 & $4.74^{*}$ \\
\hline Google+ & 4.06 & 0.86 & 3.53 & 1.31 & 1599.5 & $5.27^{*}$ \\
\hline Instagram & 4.21 & 1.08 & 3.93 & 1.13 & 2057.0 & $3,67^{*}$ \\
\hline
\end{tabular}




\begin{tabular}{|c|c|}
\hline Twitter & $4.270 .873 .941 .07 \quad 1888.5 \quad 4.26^{*}$ \\
\hline TripAdvisor & $4.320 .95 \quad 4.050 .98 \quad 2026.5 \quad 3.78^{*}$ \\
\hline Linkedln & $4.350 .85 \quad 4.06 \quad 1.07 \quad 2015.5 \quad 3,82^{*}$ \\
\hline MySpace & $\begin{array}{llllll}4.37 & 0.69 & 4.02 & 1.05 & 1859.5 & 4.36^{*}\end{array}$ \\
\hline Pokec & $\begin{array}{cccccc}4.41 & 0.68 & 4.11 & 1.02 & 1987.5 & 3.92^{*}\end{array}$ \\
\hline Foursquare & 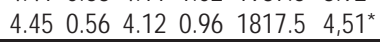 \\
\hline Search engines, price comparison websites and deal sites & \\
\hline Search engines (e.g. Google) & $\begin{array}{lllllll}2.11 & 1.15 & 2.28 & 1.26 & 2583.0 & -1.84\end{array}$ \\
\hline Deal sites (e.g. Zlava dňa) & $\begin{array}{llllll}2.38 & 1.34 & 2.55 & 1.03 & 2306.0 & -2.81^{*}\end{array}$ \\
\hline Price comparison websites (e.g. Heureka.sk) & $2.46 \begin{array}{llllll}1.32 & 2.69 & 1.22 & 2254.0 & -2.99 *\end{array}$ \\
\hline
\end{tabular}

Based on the results shown in Table 2, it can be concluded that differences were not found when using media that are well-established on the Slovak market. The differences are noticeable mainly in emerging media such as social networks, which have not found the optimal application in the Slovak market yet. It can be observed in a slight latency of their use when shopping, compared with users on the Polish market.

Results of the research:

1. If users are in a situation they should buy the product, Slovak and Polish users would search for the information about this product using selected online media the same way. Based on this finding, hypothesis $\mathrm{H} 1$ has not been confirmed while the differences in using were found only in the use of search engine, seller's website and social networks except Facebook.

2. Slovak and Polish customers did not purchase equally based on information from selected online media. Differences were not found only in the use of search engines, Facebook, e-mails and blogs. This detection therefore confirms our hypothesis $\mathrm{H} 2$.

3. Customers would mostly use search engine, website of seller, price comparison websites, deal sites and forums when intend to purchase a product.

4. De facto customers have bought the product based on the information obtained from search engines, seller's website, deal sites, price comparison sites and discussion forums.

5. Emerging online media (mostly social networks) are used more and to a greater extent on the Polish market compared to Slovak market.

The aforementioned findings cannot be generalized (because of convenience sampling), but they can be used in the future both in realization of further research in this area and also in the development of the marketing communication strategy of companies and organizations to communicate with their target audience. The presented results can influence the initial choice of online media in order to prevent inefficient spending, especially in small and medium-sized enterprises, which often operate with a limited budget.

\section{Summary}

Online media can be used to attract potentional customers, raise engagement and generate revenue. This can be achieved mainly through the product information that will influence the decision of the customer's purchase. The results of this study demonstrated that, when searching for information about relevant products, there are not significant differences in the behaviour of Slovak and Polish customers. Furthermore, it was found that the Slovak and Polish users do not use selected online media for shopping in the same way. The mostly used medium to find information about the product and the execution of purchase is the search engine. Other media, especially social networks, are not significantly used during purchasing process.

\section{References}

Alton, Y. K. Ch., Banerjee, S., 2013, Customer Knowledge Management Via Social Media: The Case of Starbucks, [in:] Journal of Knowledge Management, $17 / 2$.

Baglieri, D., Consoli, R., 2008, Learning from customers: Running virtual communities in tourism, [in:] Proceedings of the 11th ToulonVerona International Conference on Quality in services: higher education, health care, local government, tourism, banking, Firenze University Press, Firenze, Italy.

Bajdor, P., Brzeziński, S., 2013, Cause related marketing as one of the sustainable marketing's dimensions - the essence and practical examples, [in:] Polish Journal of Management Studies, 7.

Butoracová Šindleryová, I., 2015, Lifelong education - the projected vision of the regional development, [in:] 2nd International 
multidisciplinary scientific conference on SOCIAL SCIENCES and ARTS SCEM 2015, Book 1, Vol. II. Bulgaria, Albena, p. 605613.

Chan, R. Ch. H., Chu, S. K. W., Lee, C. W. Y., Chan, B. K. T., Leung, CH. K., 2013, Knowledge Management Using Social Media: A Comparative Study between Blogs and Facebook. https://www.asis.org/asist2013/proceedings/submissions/papers/81paper.pdf, Accessed on: 14.08.2015.

Chien, H. W., Shu-Chen, K., Hsin-Hui, L., 2013,Acceptance of Enterprise Blog for Service Industry, [in:] Internet Research, 23/3.

Chovancová, J., 2014, Possibilities of energyself-suffiencyimprovement in municipalities in Slovakia, [in:] Ecology, economics, education and legislation : conference proceedings, volume iii: 14th international multidisciplinary scientific geoconferences gem.

Chovancová, J., Rusko, M., 2008, Environmentálne označovanie produktov ako nástroj podpory zeleného marketingu [ecolabelling as the supporting tool for green marketing], [in:] Manažérstvo životného prostredia, zborník príspevkov z 8. konferencie so zahraničnouúčastou, Strix, Žilina, Slovakia.

Constantin, C., 2013, The necessity to improve quality in higher education services. Case of Romania, [in:] Polish Journal of Management Studies, 8.

Dima, I. C., Man, M, Kot, S., 2010,Use of Abraham Maslow's motivation theory for setting consumers' satisfaction-non-satisfaction, [in:] Polish Journal of Management Studies, 2.

Ezumah, B. A., 2013, College Students' use of Social Media: Site Preferences, Uses and Gratifications Theory Revisited, [in:] International Journal of Business and Social Science, $4 / 5$.

Ferencová, M., Hudáková, Z., 2013, On-line sociálne médiá a e-komunikácia vybraných slovenských podnikov so zákazníkmi, [in:] Podniková Revue: Vedecký časopis Podnikovohospodárskej fakulty Ekonomickej university v Bratislave so sídlom v Košiciach, $12 / 29$.

Ferencová, M, Jeleňová, I., Kakalejčík, L., 2015, Social Media Usage in Product Information Searching, [in:] Applied Mechanics and Materials, 795.

Gallo, C., 2012, Power of Foursquare: The innovative ways to get your customer to check wherever they are, McGraw-Hill, New York.

Goncharuk, A., 2015, Management education in research, [in:] Journal of Applied Management and Investments, 4/3.

Halligan, B, Shah, D., 2014, Inbound Marketing: Get found using Google, Social Media and Blogs, John Wiley \& Sons, New Jersey.

Janouch, V., 2010, Internetový marketing, Computer Press, Brno.

Karliček, M., Král, P., 2011,Marketingová komunikace: Jak komunikovat na našem trhu, Grada Publishing, Praha.

Kawasaki, G., Fitzpatrick, P., 2014, The Art of Social Media: Power Tips for Power Users, Penguin, New York.

Kincl, J., et al., 2004, Marketing podletrhů, Alfa, Praha.

Kretter, A., et al., 2008, Marketing, Slovenskápol'nohospodárskauniverzita, Nitra.

Kuss, A. , Tomczak, T., 2004, Käuferverhalten, Lucius \& Lucius,Stuttgart.

Lieb, R., 2011, Content Marketing: Think Like a Publisher - How to Use Content to Market Online and in Social Media, Que Publishing, Indianapolis.

Mohammadpour, A. et al (Eds.), 2014,A Survey of the Effect of Social Media Marketing on Online Shopping of Customers by Mediating Variables, [in:] Journal of Service Science and Management, $7 / 5$.

Parker, C., 2010, 301 Ways to Use Social Media To Boost Your Marketing, McGraw-Hill, New York.

Pocol, A. G.,2012, Modern Tools for Sales Promotion - Online Promotions, [in:] The Proceedings of the International Conference "Marketing - from Information to Decision", http://www.pulib.sk:2088/docview/1330860576?accountid=14716, Access on 05.05. 2015.

Pietrasieński, P.,Ślusarczyk, B., 2015, Internationalization of small and medium enterprises: empirical research review on barriers to entry into foreign markets, [in:] Polish Journal of Management Studies, 11/1.

Schiffman, L. G., Kanuk, L. L., 2004, Nákupní chování, Computer Press, Brno.

Ślusarczyk, B., Broniszewska, A., 2014, Entrepreneurship of women in Poland and the EU - Quantitative analysis, [in:] Polish Journal of Management Studies, 9.

Ślusarczyk, B., Herbuś, A., 2015, Higher education as a crucial factor of staff development, [in:] Polish Journal of Management Studies, 10.

Ślusarczyk, B., Kot, S., 2012, Polish government impact on foreign direct investments, [in:] Polish Journal of Management Studies, 6.

Smarandache, F., Vlăduţescu, S., 2014, Towards a Practical Communication Intervention, [in:] Review of Research and Social Intervention, 46.

Sponcil, M., Gitimu, P., 2013, Use of Social Media by College Students: Relationship to Communication and Self-Concept, [in:] Journal of Technology Research, 4.

Sterne, J., 2011, Meříme a optimalizujeme marketing na sociálních sítich, Computer Press, Brno.

Tej, J., Ali Taha, V. Sirková, M. 2013,Insight into the use of creative management techniques and methods in regional context, [in:] Journal on law, economy and management, $3 / 1$.

Trenz, M., 2015,Multichannel Commerce: A Consumer Perspective on the Integration of Physical and Electronic Channels. Springer, New York.

Vejačka, M., 2015, New Marketing Opportunities on the Web, [in:] eXclusive e-JOURNAL, 1. http://exclusiveejournal.sk/1-2015/4vejacka.pdf, Access on: 13.09.2015.

Vlăduţescu, S., 2008, From Personal and Social Relationships to Social Networks, [in:] International Journal of Education and Research, $2 / 3$. 
Vlăduțescu, Ș., 2012, Relationships and communication networks, [in:] Jurnalul Practicilor Comunitare Pozitive, 4.

Wu, W., Lee, Y., 2012, The Effect of Blog Trustworthiness, Product Attitude, and Blog Involvement on Purchase Intention, [in:] International Journal of Management \& Information Systems, 16/3.

\section{Translation of References}

Chovancová, J., Rusko, M., 2008, Ecolabelling as the supporting tool for green marketing.

Ferencová, M., Hudáková, Z., 2013, Online social media and e-communication of selected Slovak enterprises with their customers.

Janouch, V., 2010, Internet marketing.

Karlíček, M., Král, P., 2011, Marketing communication: How to communicate on our market.

Kincl, J., et al., 2004, Marketing according to markets.

Kuss, A. , Tomczak, T., 2004, Consumer behavior.

Schiffman, L. G., Kanuk, L. L., 2004, Purchasing behavior.

Sterne, J., 2011, Measuring and optimization of social media marketing. 